\title{
DIVERSITY OF DRY GRASSLANDS IN THE POVAŽSKÝ INOVEG MTS (SLOVAKIA) - A NUMERICAL ANALYSIS
}

\author{
Daniela MICHÁLKOVÁ*
}

\begin{abstract}
The paper reveals a numerical and ecological analysis of 128 published relevés of xerothermic vegetation of the Považský Inovec Mts. Four associations have been recognised: Festuco valesiacae-Stipetum capillatae Sillinger 1930, Festuco pallentis-Caricetum humilis Sillinger 1930 corr. Gutermann et Mucina 1993, Poo badensis-Festucetum pallentis Klika 1931 corr. Zólyomi 1966 nom. invers. propos. and Minuartio setaceae-Seslerietum coeruleae Klika 1931 nom. mut. propos. Through the numerical methods, the study reconsiders the conception of the dry grassland associations, which are traditionally used in phytocoenological literature. It also defines the indication taxa group of the associations and characterises their environmental conditions. Major environmental gradients influencing the vegetation were interpreted using average Ellenberg indication values. Finally, the classification within the higher vegetation units, the nomenclature of the associations and the environmental threats are discussed.

Key words: classification, cluster analysis, dry grasslands, Festucetalia valesiacae, ordination, Považský Inovec Mts, Slovakia, syntaxonomy.

\section{Izvleček}

V članku je prikazana numerična in ekološka analiza 128 objavljenih popisov kserotermne vegetacije hribovja Považský Inovec. Ugotovljene so štiri asociacije: Festuco valesiacae-Stipetum capillatae Sillinger 1930, Festuco pallentis-Caricetum humilis Sillinger 1930 corr. Gutermann et Mucina 1993, Poo badensis-Festucetum pallentis Klika 1931 corr. Zólyomi 1966 nom. invers. propos. in Minuartio setaceae-Seslerietum coeruleae Klika 1931 nom. mut. propos. Z numeričnimi metodami je avtorica ponovno preverila sinsistem asociacij suhih travnikov, ki so omenjene v fitocenološki literaturi. Opredelila je skupine značilnih vrst asociacij in značilnosti rastiščnih razmer. S povprečnimi Ellenbergovimi indikacijskimi vrednostmi so prikazani glavni ekološki gradienti, ki vplivajo na floristično sestavo vegetacije suhih travišč. Članek obravnava uvrstitev asociacij v višje sintaksonomske enote, nomenklaturo asociacij in njihovo ogroženost.

Ključne besede: klasifikacija, klastrska analiza, suha travišča, Festucetalia valesiacae, ordination, Považský Inovec, Slovaška, sintaksonomija.
\end{abstract}

\section{INTRODUCTION}

The Považský Inovec Mts are located in the western part of Slovakia along the river Váh in the prae-Carpathian limestone zone (Fig. 1). The central part of the mountains, the Tematínske kopce Hills, is built up by dolomites. In this area, the numerous dry grasslands are located. However, the potential vegetation of this area are the forests, mostly the oak-hornbeam forests (Carici pilosae-Carpinetum) and locally the thermophilous oak forests (Quercion pubescentis-petraeae; Michalko et al. 1987). The major part of the forest cover had been destroyed during the Turkish war approximately in the $16^{\text {th }}$ and $17^{\text {th }}$ century. These areas later became grasslands.

The dry grassland vegetation is geographically influenced from two directions. From the south, the study area is in near contact with the eu-Pannonian lowland region, which influences the vegetation by numerous Pontic-Pannonian and subMediterranean thermophilous species. From the north, the Carpathian mountain species descend

* Slovak Academy of Sciences, Institute of Botany, Dúbravská cesta 14, SK-845 23 Bratislava, Slovakia. E-mail: daniela. michalkova@savba.sk 


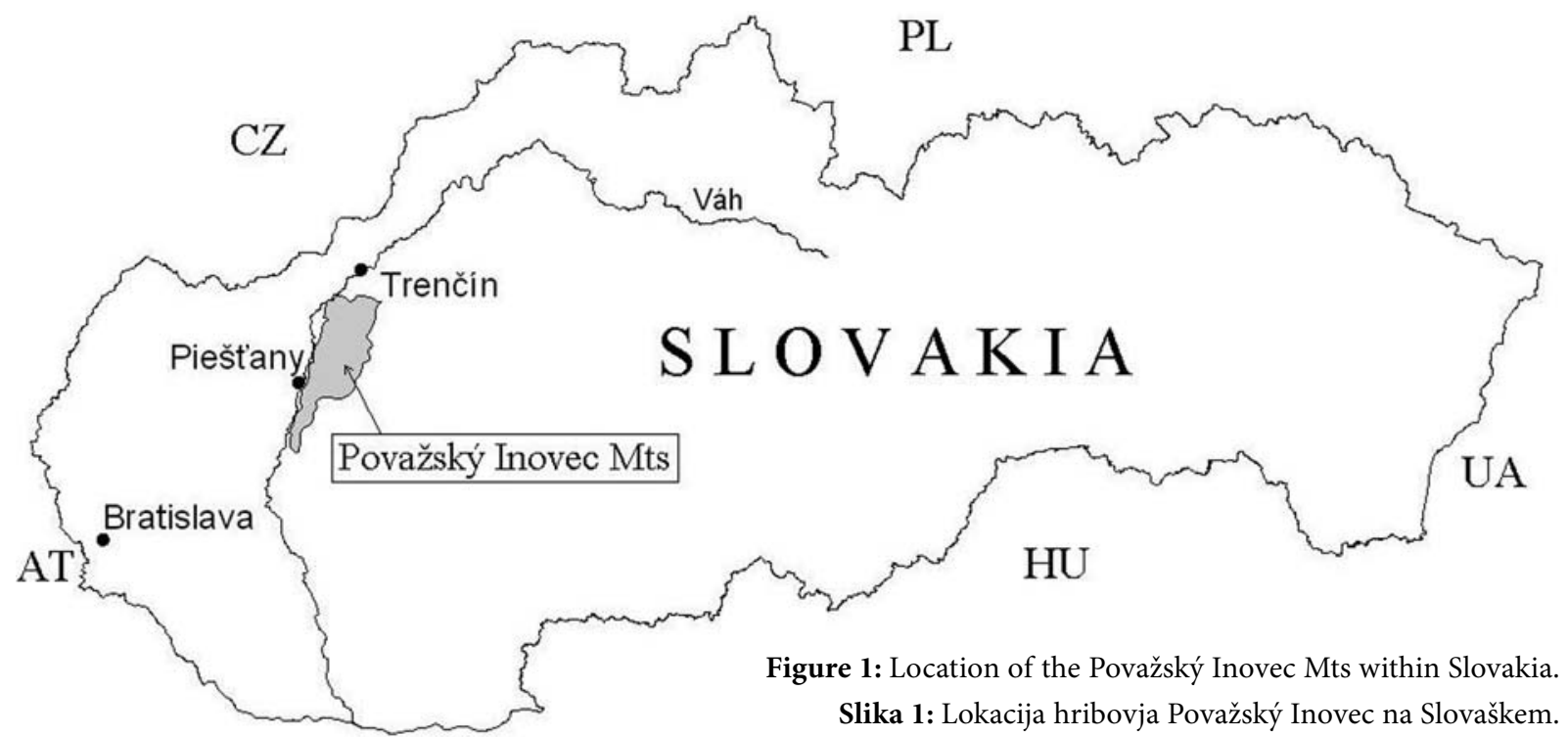

and build up some dealpine and praealpine elements (Deván et al. 2006).

This vegetation is interesting from the floristical, historical as well as the successional point of view. It was studied in detail only in two older works (Sillinger 1930, Maglocký 1979). Although some works have recently been done (Michálková, Škodová \& Mertanová 2006; Janišová 2005, 2006a, b, 2007a, b), no numerical analysis has been performed so far. The presented paper brings a numerical classification of all published relevés. The use of numerical methods endeavours to support or eventually correct the current phytosociological scheme of the dry grasslands of the study area. The aim is also to define the indication taxa group of the associations and some characteristics of their environmental conditions.

\section{MATERIAL AND METHODS}

The numerical analyses were performed using the published relevés of xerothermic vegetation of the Považský Inovec Mts, created by applying the standard Central-European method (Braun-Blanquet 1964, Westhoff \& van der Maarel 1973). The analysed data set comprised 128 relevés from the works Maglocký (1979), Sillinger (1930), Klika (1931) and Michálková, Škodová \& Mertanová (2006). The taxa determined only on the level of genus were excluded from the analyses. The layer $\mathrm{E}_{0}$ was excluded as a whole, because mosses and lichens were not determined in all relevés analysed. Some taxonomically problematic species, which were not distinguished by all authors of the relevés, were classified within higher or more broadly defined taxa: Anthyllis vulneraria agg. (subsp. polyphylla), Artemisia campestris (subsp. lednicensis), Colymbada scabiosa agg. (C. badensis), Dactylis glomerata agg. (D. polygama), Acosta rhenana agg. (Acosta biebersteinii), Helianthemum grandiflorum s. 1. (subsp. grandiflorum, subsp. obscurum, H. nummularium), Pulsatilla slavica (P. subslavica), Primula veris (subsp. canescens), Thalictrum minus (subsp. pseudominus).

Initial data analysis to remove outlier relevés (relevés, of which the species composition did not correspond to the rest of the analysed data set) was carried out using the CANOCO 4.5 package (ter Braak \& Šmilauer 2002). It was necessary to exclude 4 relevés (Maglocký 1979: Table 23, relevés 1-3; Table 25, relevé 20). There were 124 relevés used in the subsequent classification. We compared the results of more types of cluster analyses carried out by using different algorithms. The paper presents the results of the cluster analysis processed by the program PC-ORD 4 (McCune \& Mefford 1999) where Ward's method and the relative Euclidean distance as a resemblance measure were applied. These results proved to be floristically and ecologically well interpretable and were supported by our field experience as well.

Diagnostically important taxa for the individual clusters were determined by calculating the constancy and fidelity measure of each species to each cluster, using the phi coefficient of association (Sokal \& Rohlf 1995, Chytrý et al. 2002) in the program Juice (Tichý 2002). The results of the classification were summarised in a synoptic 
table (Table 1), in which both percentage species frequencies (constancies) and fidelities ( $\varphi$ coefficient multiplied by $100, \mathrm{p}<0.001$ ) were shown, and diagnostic species were ranked by decreasing fidelity (Chytrý et al. 2002). Fisher's exact test excluded the accidental species with high fidelity measures (Tichý \& Holt 2006). The threshold values of the indication taxa group were selected subjectively: fidelity of diagnostic species was higher than $40 \%$; constant species were those with a relative constancy value higher than $60 \%$; dominant species were defined as all species that had cover values higher than $30 \%$. The number values indicate fidelity for the diagnostic species and constancy for the constant species in the chapter "Nomenclature and species characteristics of the associations". There is also a number given to each dominant species, which stands for the percentage of relevés meeting the threshold criteria. The indication taxa group of each cluster was compared to the diagnostic species from Holub et al. (1967), Chytrý et al. (2007) and Mucina \& Kolbek (1993), which enabled interpretation of the associations in terms of higher phytosociological units (orders and alliances, Tab. 1).

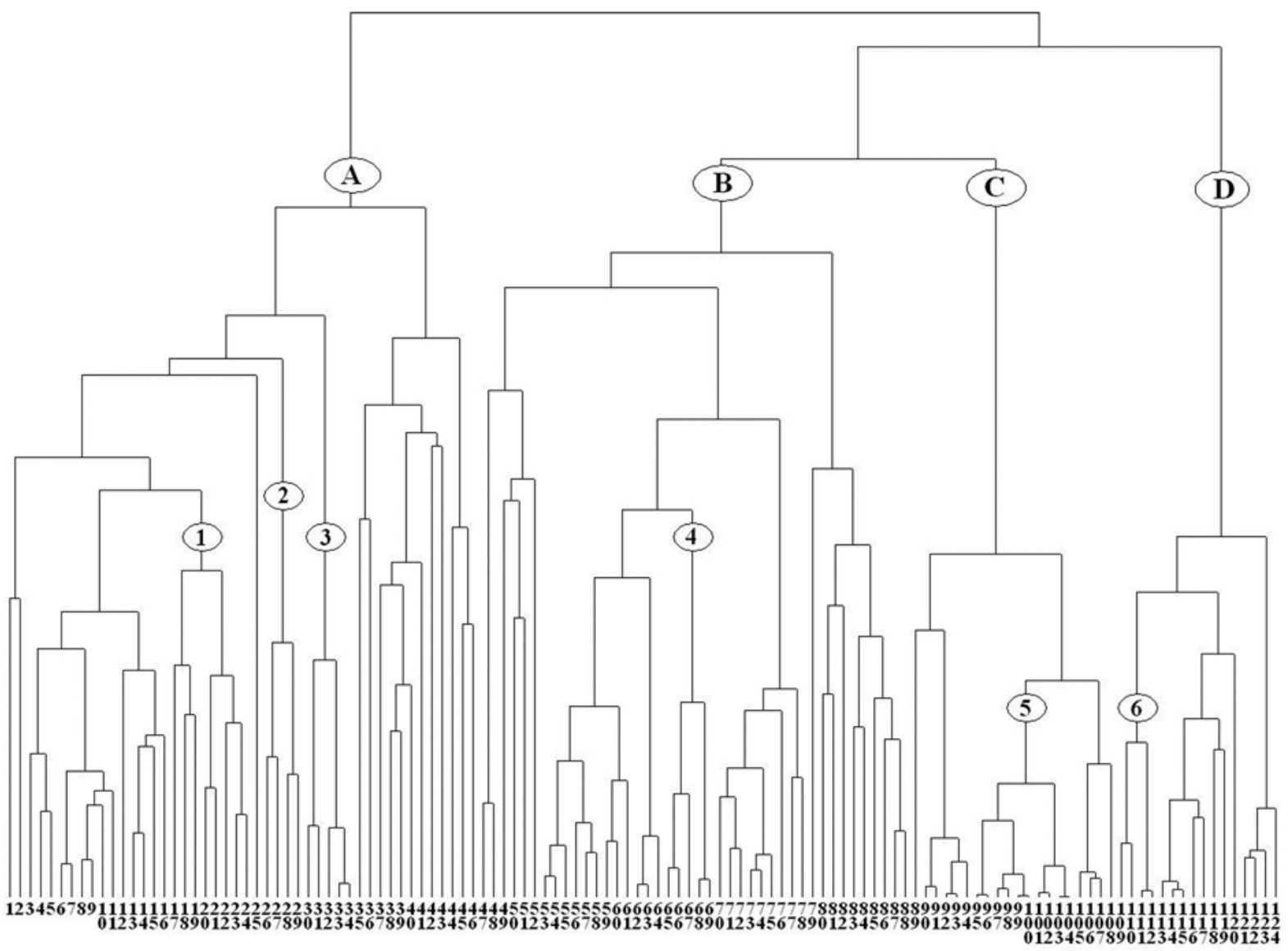

Figure 2: Dendrogram of the cluster analysis (Ward's method, relative Euclidean distance).

Slika 2: Dendrogram klastrske analize (Wardova metoda, relativna Evklidska razdalja).

A - Festuco valesiacae-Stipetum capillatae (1 - festucetosum rupicoae, 2 - botryochloetosum ischaemii, 3 - caricetosum caryophyllae), B - Festuco pallentis-Caricetum humilis (4 - typicum, Koeleria macrantha-variant), C - Poo badensis-Festucetum pallentis (5 - jovibarbetosum hitrae), D - Minuartio setaceae-Seslerietum caeruleae (6 - festucetosum pallentis).

Sources of relevés (Viri popisov): Cluster A: 1-2 - d: rel. 1, 2; 3-24 - a: Table 27, rel. 4, 12, 16, 5, 7, 6, 20, 9, 8, 28, 29, 32, 34, 33, 17, 18, 19, 21, 22, 23, 24, 25; 25 - d: rel. 3; 26-34 - a: Table 27, rel. 26, 27, 30, 31, 10, 11, 13, 14, 15; 35-36 - d: rel. 4, 5; 37 - Chytrý 1995, ined.; 38-40 - a: Table. 27, rel. 1, 2, 3; 41-43 - b: p. 36, rel. 2, 1, 3; 44-46 - d: rel. 6-8; Cluster B: 47-48 - d: rel. 9, 10; 49-52 - b: p. 36, rel. 4, 5, 6, 7; 53 - c: p. 363, rel. 14; 54 - a: Table 26, rel. 18; 55 - c: p. 363, rel. 15; 56-78 - a: Table 26, rel. 14, $21,23,5,15,8,19,20,22,11,12,13,16,17,1,6,7,4,24,10,3,2,9 ; 79-88$ - d: rel. 11-20; Cluster C: 89 - c: p. 363, rel. 13; 90-108 - a: Table 22, rel. 2, 6, 7, 9, 11, 1, 15, 8, 10, 14, 16, 13, 17, 18, 19, 3, 4, 5, 12; Cluster D: 109 - c: p. 370, rel. 29; 110-124 - a: Table 25, rel. 3, 2, 6, 10, 13, 15, 12, 21, 24, 25, 22, 16, 18, 17, 23. Abreviations (Okrajšave): a - Maglocký (1979), b - Sillinger (1930), c - Klika (1931), d - Michálková, Škodová \& Mertanová (2006). 


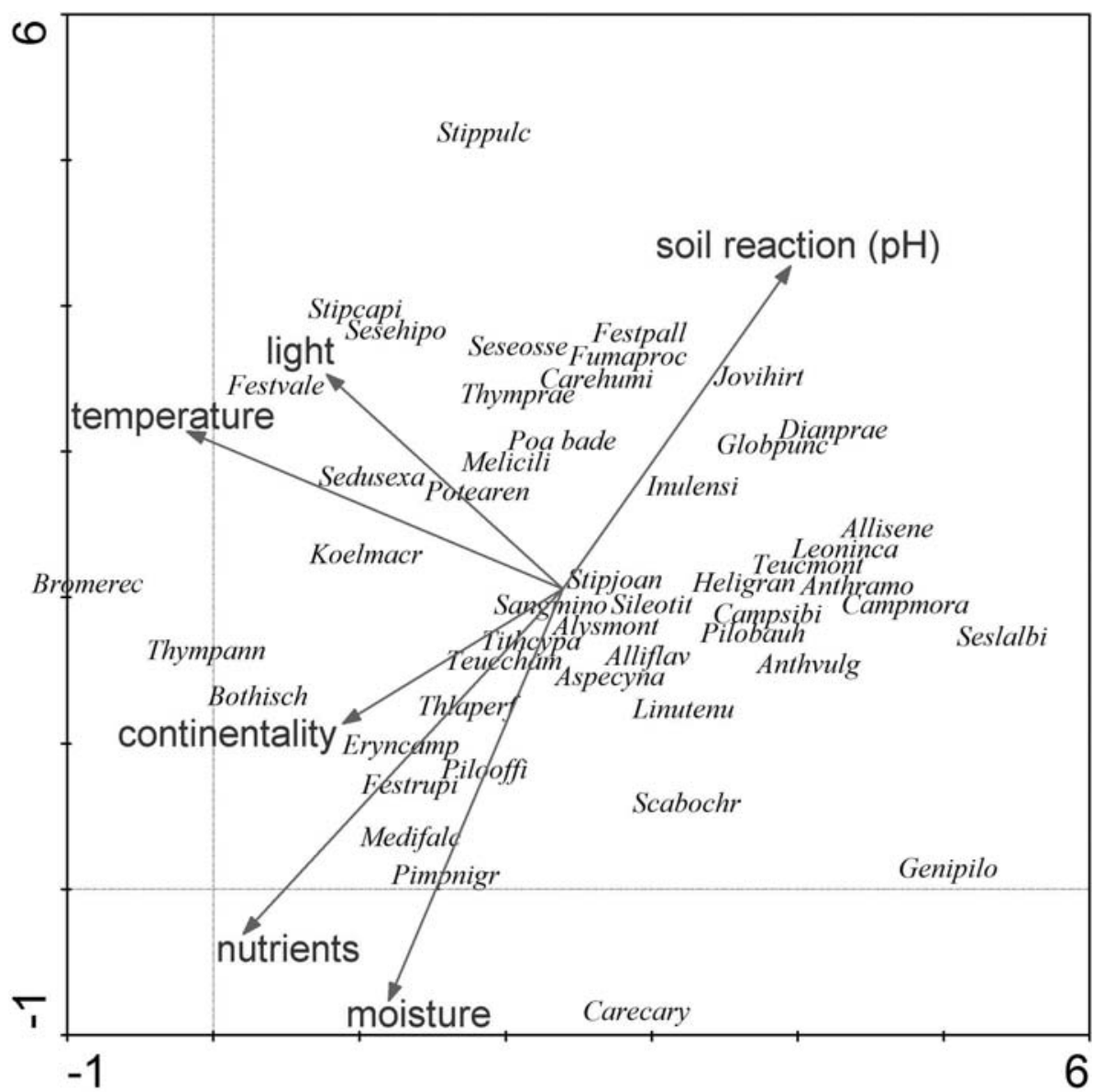

Figure 3: Detrended correspondence analysis (DCA) ordination diagram of the species occurring in the dry grassland vegetation of the Považský Inovec Mts.

Slika 3: Ordinacijski diagram korespondenčne analize z odstranjenim trendom (DCA) floristične sestave suhih travnikov na hribovju Považský Inovec.

Species list (Seznam vrst): Allium flavum, A. senescens ssp. montanum, Alyssum montanum, Anthericum ramosum, Anthyllis vulneraria, Asperula cynanchica, Bothriochloa ischaemum, Bromus erectus, Campanula moravica, C. sibirica, Carex caryophyllea, C. humilis, Dianthus praecox ssp. lumnitzerii, Eryngium campestre, Festuca pallens, F. rupicola, F. valesiaca, Fumana procumbens, Genista pilosa, Globularia punctata, Helianthemum grandiflorum, Inula ensifolia, Jovibarba hirta ssp. glabrescens, Koeleria macrantha, Leontodon incanus, Linum tenuifolium, Medicago falcata, Melica ciliata, Pilosella bauhinii, P. officinarum, Pimpinella nigra, Poa badensis, Potentilla arenaria, Sanguisorba minor, Scabiosa ochroleuca, Sedum sexangulare, Seseli hippomarathrum, S. osseum, Sesleria albicans, Silene otites, Stipa capillata, S. joannis, S. pulcherrima, Teucrium chamaedrys, T. montanum, Thlaspi perfoliatum, Thymus pannonicus, T. praecox, Tithymalus cyparissias.

The ordination techniques, using the detrended correspondent analysis (DCA) from the CANOCO 4.5 package, defined the major gradients in the spatial arrangement of species of the analysed data set. For ecological interpretation of the ordination axes, average Ellenberg indication values (Ellenberg et al. 2001) for relevés were plotted onto a DCA ordination diagram as supplementary environmental data (Fig. 3 and 4).

The nomenclature of vascular plants follows Marhold \& Hindák (1998). The nomenclature of higher syntaxa is in accordance with Chytrý et al. (2007) and Mucina \& Kolbek (1993). Phytosociological nomenclature of associations is reconsidered according to Weber, Moravec \& Theurillat (2000). For the individual associations, these abbreviations were used in Fig. 4 and 5: Fv-Sc - Festuco valesiacae-Stipetum capillatae, Fp-Ch - Festuco pallentis-Caricetum humilis, $\mathbf{P b}-\mathbf{F p}$ - Poo badensis-Festucetum pallentis and Ms-Sc - Minuartio setaceae-Seslerietum caeruleae. 

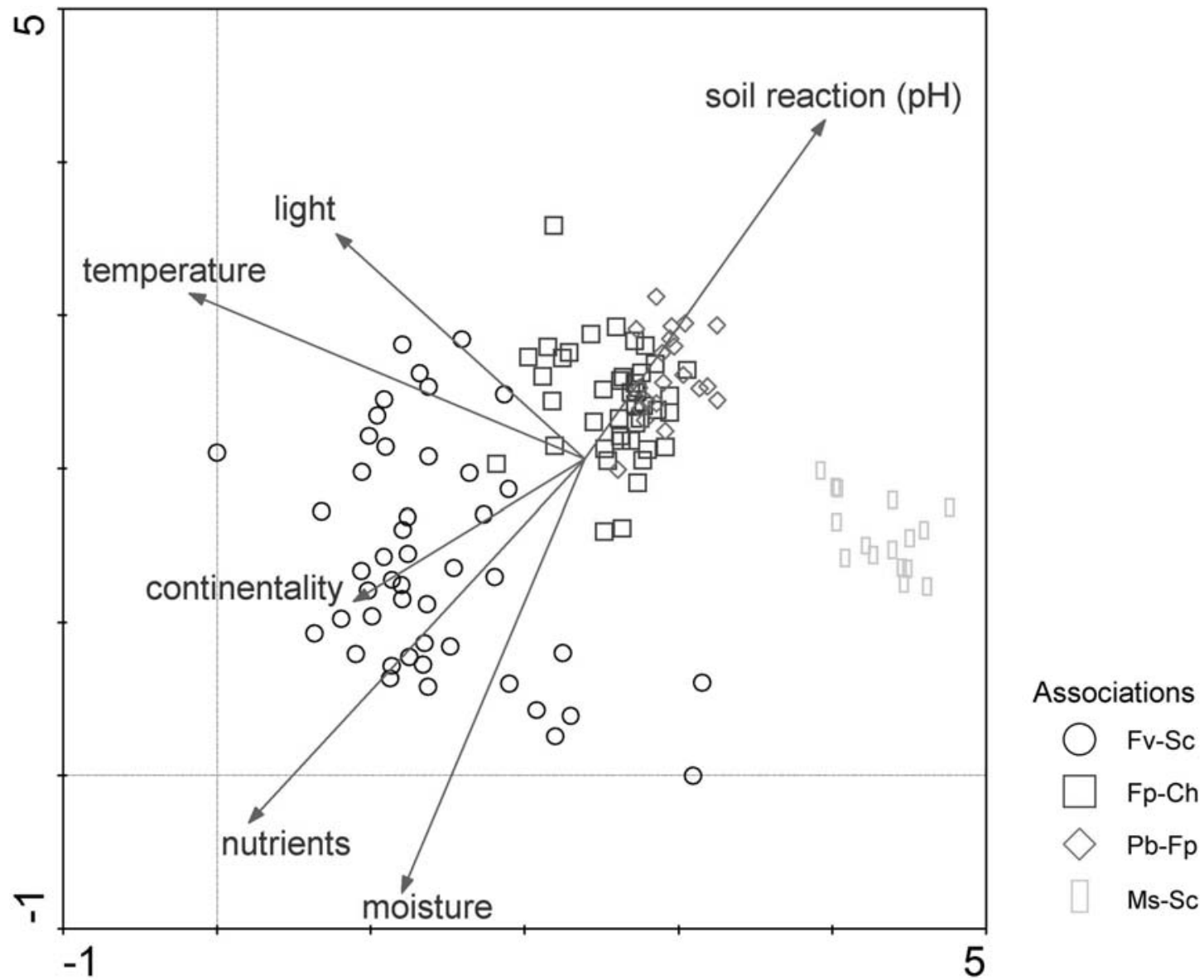

Figure 4: Detrended correspondence analysis (DCA) ordination diagram of the relevés, based on average Ellenberg indicator values.

Slika 4: DCA ordinacijski diagram popisov na osnovi povprečnih Ellenbergovih indikacijskih vrednosti.

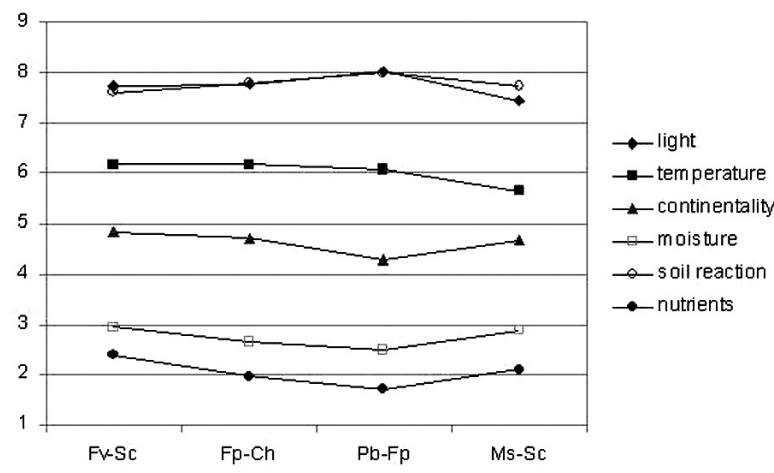

Figure 5: Average Ellenberg indication values of the ecological factors of vascular plants occurring in individual clusters (associations) produced as outputs of the cluster analysis.

Legend (Ellenberg et al. 2001): Light: 7 - plants in well lit places, sometimes occurring in partial shade, 8 - light-loving plants. Temperature: 5 - indicator of fairly warm condition, 7 - warmth indicator. Continentality: 4 - sub-oceanic,
5 - intermediate. Moisture: 1 - indicator of extreme dryness, 3 - dry sites indicator. Soil reaction: 7 - indicator of weekly acid to weekly basic conditions, never found on very acid soils, 9 - basic reaction and lime indicator. Nutrients: 1 - indicator of sites extremely poor in available nitrogen, 3 - indicator of sites more or less poor in available nitrogen.

Slika 5: Povprečne Ellenbergove indikacijske vrednosti posameznih klastrov (asociacij). ki so rezultat klastrske analize.

Legenda (Ellenberg et al. 2001): Svetloba: 7 - rastline svetlobe, včasih uspevajo $\mathrm{v}$ delni senci, 8 - rastline svetlobe. Temperatura: 5 - nakazovalke zmerno toplih razmer, 7 - indikatorji relativno toplih razmer. Kontinentalnost: 4 - suboceanske razmere, 5 - vmesne razmere. Vlažnost: 1 - indikatorji skrajno sušnih razmer, 3 - indikatorji sušnih razmer. Kemična reakcija tal: 7 - indikatorji slabo kislih oziroma slabo bazičnih tal, tovrstnih rastlin nikoli ne najedmo na zelo kislih tleh, 9 - nakazovalke bazične reakcije ali zelo karbonatnih tal. Hrabnila: 1 - nakazovalke rastišč, najrevnejših z razpoložljivim dušikom, 3 - nakazovalke rastišč, revnih z razpoložljivim dušikom. 


\section{RESULTS}

\subsection{Cluster analysis}

Interpreting the results of the cluster analysis, four associations have been distinguished in the dendrogram at the third highest level of dissimilarity (Fig. 2). They are: Festuco valesiacae-Stipetum capillatae
Sillinger 1930 (Fig. 6), Festuco pallentis-Caricetum humilis Sillinger 1930 corr. Gutermann et Mucina 1993 (Fig. 7), Poo badensis-Festucetum pallentis Klika 1931 corr. Zólyomi 1966 nom. invers. propos. and Minuartio setaceae-Seslerietum calcariae Klika 1931 nom. mut. propos. All of these vegetation units, using different synonyms, have been traditionally diagnosed in the phytocoenological literature (cf. Maglocký 1979).

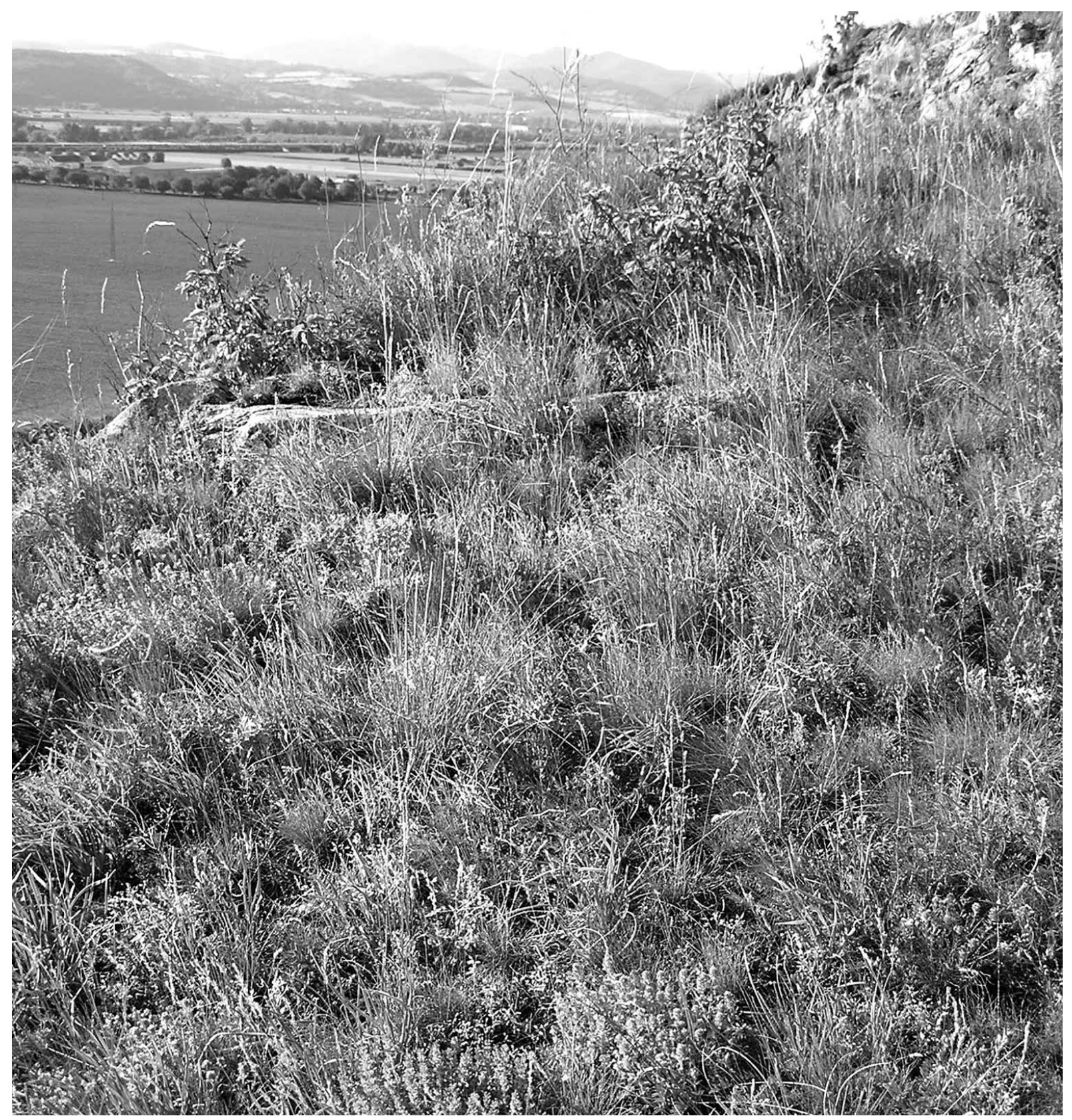

Figure 6: Festuco valesiacae-Stipetum capillatae in the Nature Reserve Beckovské skalice (township of Beckov). Photo: D. Michálková, 19. 7. 2005.

Slika 6: Asociacija Festuco valesiacae-Stipetum capillatae v naravnem rezertvatu Beckovské skalice (občina Beckov). Foto: D. Michálková, 19. 7. 2005. 


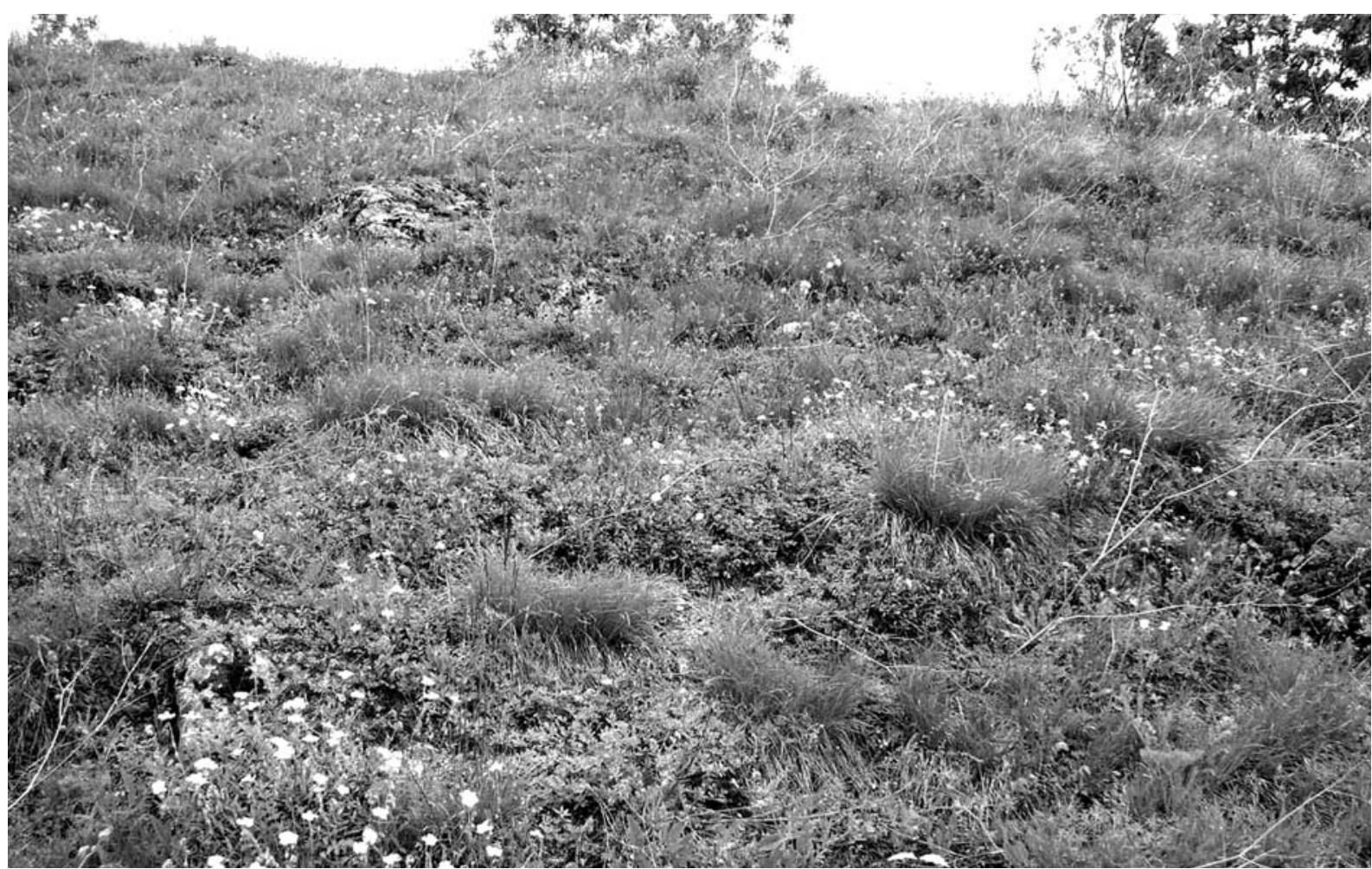

Figure 7: Spring aspect of Festuco pallentis-Caricetum humilis. Photo: M. Janišová, 24. 5. 2005.

Slika 7: Spomladanski aspekt asociacije Festuco pallentis-Caricetum humilis. Foto: M. Janišová, 24. 5. 2005.

\subsubsection{Nomenclature and species characte- ristics of the associations (cf. Table 1)}

\section{Cluster A - Festuco valesiacae-Stipetum capillatae Sil- linger 1930}

Orig. (Sillinger 1930: 35): Festuceto (valesiacae)-Stipetum capillatae

Phantom name: Festuco valesiacae-Stipetum capillatae Sillinger 1931 (in Mucina \& Maglocký 1985: 189), Stipo capillatae-Festucetum valesiacae Sillinger 1931 (in Maglocký 1979: 92)

Nomenclatural type: Sillinger 1930: 36, rel. 3, holotypus

Remark: We considered the possibility of suggesting the inversion of the order of species names in Festuco valesiacae-Stipetum capillatae Sillinger 1930. Festuca valesiaca seems to dominate over Stipa capillata in the growths of this association and therefore it should stay in the second position of the association's name (Art. 10b). However, Stipa capillata grows at the higher herb level compared to Festuca valesiaca and it dominates in a few stands in Southern Moravia (Chytrý in litt.). For these reasons we decided to keep the name in its original form described by Sillinger (1930).

Diagnostic taxa: Festuca valesiaca 77.8, Medicago falcata
74.4, Eryngium campestre 69.1, Securigera varia 61.5, Pimpinella nigra 60.8, Acosta rhenana agg. 57.7, Thymus pannonicus 54.4, Festuca rupicola 52.9, Carex caryophyllea 49.8, Koeleria macrantha 48.5, Astragalus onobrychis 47.8, Medicago lupulina 47.8, Plantago lanceolata 46.7, Poa angustifolia 46.4, Salvia pratensis 45.7, Fragaria viridis 44.6, Teucrium chamaedrys 44.2, Adonis vernalis 41.5, Agrimonia eupatoria 41.5, Galium verum 41.5, Achillea collina 41.4, Ranunculus bulbosus 40.4

Constant taxa: Sanguisorba minor 83, Potentilla arenaria agg. 74, Tithymalus cyparissias 72, Asperula cynanchica 61 , Pilosella officinarum 61

Dominant taxa: Festuca valesiaca 22, Bothriochloa ischaemum 11, Carex caryophyllea 9

\section{Cluster B - Festuco pallentis-Caricetum humilis Sillin- ger 1930 corr. Gutermann et Mucina 1993}

Orig. (Sillinger 1930: 28): Asociace Festuca glaucaCarex humilis (Glauceto-Caricetum humilis)

Syntax. syn.: Scabioso suaveolentis-Caricetum humilis Klika 1931

Nomenclatural type: Michálková, Škodová \& Mertanová (2006): Table 1, rel. 12, lectotypus hoc loco.

Diagnostic taxa: Alyssum montanum 55.0, Stipa joannis 
51.5, Poa badensis 47.2, Colymbada scabiosa agg. 41.0, Carex humilis 40.5

Constant taxa: Helianthemum grandiflorum s. lat. 93, Thymus praecox 93, Sanguisorba minor 93, Globularia punctata 86, Tithymalus cyparissias 86, Potentilla arenaria agg. 83, Teucrium montanum 83, Festuca pallens 76, Leontodon incanus 69, Anthyllis vulneraria agg. 64, Linum tenuifolium 64, Asperula cynanchica 62

Dominant taxa: Carex humilis 55, Stipa joannis 12

Cluster C - Poo badensis-Festucetum pallentis Klika 1931 corr. Zólyomi 1966 nom. invers. propos.

Orig. (Klika 1931: 360): Festuca glauca-Poa badensisAssoziation

Nomenclatural type: Klika 1931: 363, rel. 16, lectotypus (assigned in Toman 1975)

Diagnostic taxa: Fumana procumbens 54.8, Festuca pallens 50.5, Draba lasiocarpa 44.6

Constant taxa: Teucrium montanum 100, Thymus praecox 100, Helianthemum grandiflorum s.lat. 85, Leontodon incanus 85, Globularia punctata 65, Potentilla arenaria agg. 65 Dominant taxa: Festuca pallens 30, Poa badensis 5

Cluster D - Minuartio setaceae-Seslerietum caeruleae Klika 1931 nom. mut. propos.

Orig. (Klika 1931: 367): Sesleria calcaria-Alsine setacea-Assoziation (Alsine setacea $=$ Minuartia setacea , Sesleria calcaria $=S$. caerulea, Art. 45)

Syn.: Seslerio-Caricetum humilis Sillinger 1930 (Art. 31), Carici humilis-Seslerietum calcariae Sillinger 1930 nom. invers. (Art. 31)

Non: Carici humilis-Seslerietum calcariae Zlatník 1928 Nomenclatural type: Klika 1931: 369, rel. 21, lectotypus (assigned in Toman 1975)

Diagnostic taxa: Sesleria albicans 96.9, Genista pilosa 74.2, Thalictrum minus 70.1, Thesium linophyllon 67.0, Phyteuma orbiculare 60.7, Allium senescens ssp. montanum 56.6, Thlaspi montanum 55.7, Bupleurum falcatum 51.2, Polygala amara ssp. brachyptera 51.0, Campanula moravica 50.0, Bromus monocladus 44.7, Carex humilis 40.5

Constant taxa: Teucrium montanum 100, Helianthemum grandiflorum s.lat. 88, Anthericum ramosum 81, Leontodon incanus 75, Sanguisorba minor 69, Globularia punctata 62 Dominant taxa: Sesleria albicans 100, Genista pilosa 25

\subsection{Ordination and analysis of Ellenberg indication values}

The detrended gradient analysis (DCA) has been used to define the major gradients in the species composition of the dry grassland vegetation (Fig. 3 and 4 , Table 2 ). Figure 4 shows the species scatter plot of DCA based on individual relevés. Ellenberg indication values, plotted onto the ordination diagram, show that the major variation in species composition of the dry grasslands corresponds to the combination of several gradients. The first axis of the ordination diagram interprets $7.6 \%$ of the variability of the data set (lengths of gradient 4.763, eigenvalue 0.642 ) and it may be more or less associated with the temperature gradient. The second axis (lengths of gradient 3.587, eigenvalue 0.398) is associated with the soil reaction gradient, which negatively correlates to the moisture (which could be later combined with the soil nutrient availability gradient).

Individual clusters strikingly differ in their relationships to major environmental factors (Fig. 3 and 4). Connected to the temperature gradient, vegetation of cluster A (Festuco valesiacae-Stipetum capillatae) occupies very warm sites, while cluster D (Minuartio setaceae-Seslerietum caeruleae) is confined to the coolest sites. The gradients of soil nutrients and moisture are mutually correlated, with cluster A (Festuco valesiacae-Stipetum capillatae) associated with high values and clusters B (Festuco pallentisCaricetum humilis) and C (Poo badensis-Festucetum pallentis) with low values.

There is a relatively variable association of Festuco valesiacae-Stipetum capillatae dissociated in the left lower part of the diagram. In comparison to the rest of the data set, this unit includes the vegetation of warm and moist stands, which are the richest in soil nutrients and the most continental (Fig. 5). This closed vegetation occurs in the stands with deeper soil, which indicates also its species composition (Table 1). These dry grasslands were used as pastures in the past. They occur in the near vicinity of the rural settlements on the slight slopes at lower altitudes.

There are relevés of Minuartio setaceae-Seslerietum caeruleae separated in the right part of the ordination space (Fig. 4). This is the most cool-liking association, in which some mountain plant species are present. Sesleria albicans, Phyteuma orbiculare and Acinos alpinus are the examples of the dealpine species, while Leontodon incanus, Thlaspi montanum and Biscutella laevigata are the prealpine taxa. In comparison to the other associations, Minuartio setaceae-Seslerietum caeruleae grows in the humid stands and it does not have high light requirements (Fig. 5). It occurs at the highest altitudes in the NE to NW expositions. Bromus monocladus (B. pannonicus ssp. monocladus), a remarkable endemic of the Western Carpathians, prefers less extreme, mesophilous stands. 
Table 2: The outputs of the detrended correspondence analysis (DCA) of the phytocoenological relevés of the dry grassland vegetation of the Považský Inovec Mts.

\begin{tabular}{lccccc} 
Axes & $\mathbf{1}$ & $\mathbf{2}$ & $\mathbf{3}$ & $\mathbf{4}$ & Total inertia \\
\hline Eigenvalues: & 0.642 & 0.398 & 0.329 & 0.192 & 8.461 \\
$\begin{array}{l}\text { Lengths of gradient: } \\
\begin{array}{l}\text { Cumulative percentage } \\
\quad\end{array}\end{array}$ & 4.763 & 3.587 & 3.533 & 2.228 & \\
$\begin{array}{l}\text { variance of spec. data: } \\
\text { Sum of all eigenvalues }\end{array}$ & 7.6 & 12.3 & 16.2 & 18.5 & \\
\hline
\end{tabular}

There are two associations (Festuco pallentis-Caricetum humilis and Poo badensis-Festucetum pallentis) located in the central part of the diagram (Fig. 4). Their inter-separation is rather poorly presented in this projection of the ordination space. Both associations positively correlate to the increasing of the basic character of the substrate and negatively to the amount of soil nutrients and moisture. The more extreme open vegetation of Poo badensis-Festucetum pallentis naturally occurs on the dolomite and limestone screes with the minimal amount of soil available, which contains nutrients and holds water.

\subsection{Exposition and inclination of the slopes}

The exposition of slopes is an important environmental factor, which influences the distribution of dry grassland associations in the study area (MAGLOCKÝ 1978, JANIŠOvÁ 2005). While the Minuartio setaceae-Seslerietum caeruleae evidently prefers the northern expositions, all the other associations tend to occur mostly on the south facing slopes (Fig. 8). The Festuco valesiacae-Stipetum capillatae occurs on
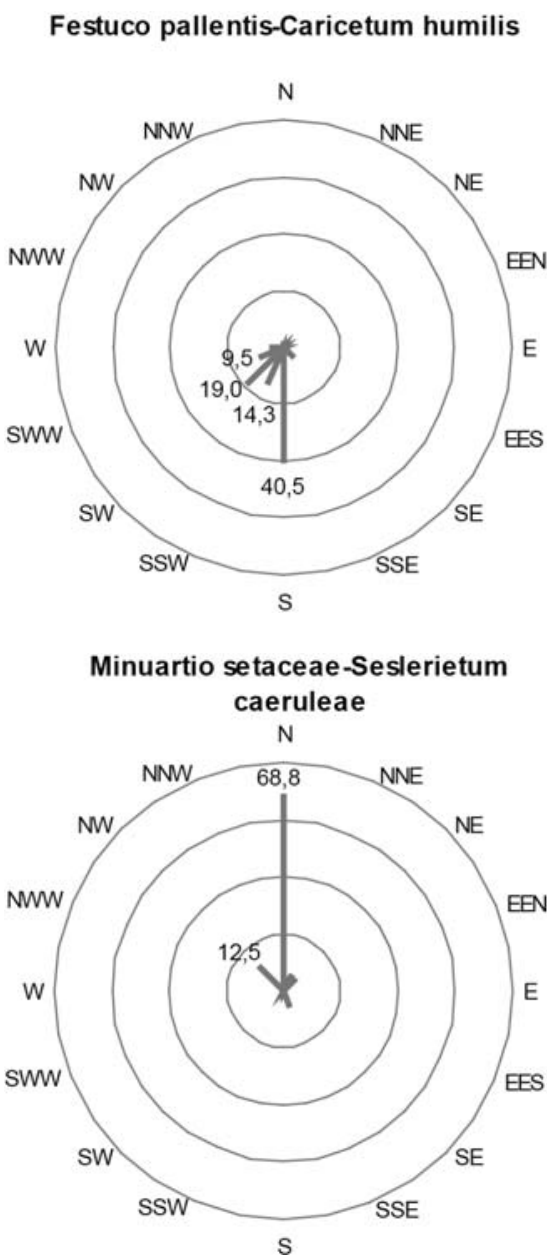

Figure 8: Circle diagrams indicating the slope exposition priorities of the associations. Grey circle scale measures show 20, 40, 60 and $80 \%$. The number values are marked starting from $9 \%$.

Slika 8: Krožni diagrami prikazujejo nebesno lego in naklon rastišč posameznih asociacij. Sivi krogi prikazujejo naklon: 20 , 40, 60 in $80 \%$. Vrednosti so označene od naklona $9 \%$ navzgor. 
the slight slopes (Tab. 1, average inclination $11^{\circ}$ ) in the warm expositions (S, SW, W). The driest association Poo badensis-Festucetum pallentis prefers south to east facing slopes, which are relatively steep (average inclination $26^{\circ}$ ). Festuco pallentis-Caricetum humilis grows usually in south to west expositions, mostly at the ridges of the hills (Fig. 9).

\section{SYNTAXONOMY}

Festuco-Brometea Br.-Bl. et Tx. ex Soó 1947

Festucetalia valesiacae Br.-Bl. et Tx. ex Br.-Bl. 1949

Festucion valesiacae Klika 1931

Festuco valesiacae-Stipetum capillatae Sillinger 1930

Bromo pannonici-Festucion pallentis Zólyomi 1936 corr. 1966

Festuco pallentis-Caricetum humilis Sillinger 1930 corr. Gutermann et Mucina 1993

Poo badensis-Festucetum pallentis Klika 1931 corr. Zólyomi 1966 nom. invers. propos.

Diantho lumnitzeri-Seslerion albicantis (Soó 1971)

Chytrý et Mucina in Mucina et Kolbek 1993

Minuartio setaceae-Seslerietum caeruleae Klika 1931 nom. mut. propos.

The classification of the associations within the class Festuco-Brometea is rather problematic. The traditional conception of the class division into orders and alliances (cf. Mucina \& Maglocký 1985) is not identical to the more recent works (cf. Mucina \& Kolbek 1993, Michálková \& Šibík 2006, Chytrý et al. 2007).

Only the classification of the Festuco valesiacaeStipetum capillatae appears to be definite, because both in the traditional and modern literature sources, the association is classified within the subcontinental alliance Festucion valesiacae (cf. Maglocký 1979, Mucina \& Maglocký 1985, Moravec et al. 1995, Chytrý et al. 2007).

The author of the description of Festuco pallentis-Caricetum humilis did not classify this association within any higher syntaxon. At the time of its publication in Sillinger (1930), no alliances of the class Festuco-Brometea had yet been described. On the other hand, the association Scabioso suaveolentisCaricetum humilis (syntax. syn. of the Festuco pallentis-Caricetum humilis) was included by the author of its description in Festucion valesiacae (Klika 1931). Later some authors followed this conception (Maglocký 1979, Mucina \& Maglocký 1985). These dry grasslands are classified in the works of Mucina \&
Kolbek (1993: 475) and Chytrý et al. (2007) within Bromo pannonici-Festucion pallentis. This alliance includes the circum-Pannonian thermophilous grassland biotopes on dolomite bedrocks.

The association Poo badensis-Festucetum pallentis is classified in Mucina \& Kolbek (1993: 473) and Chytrý et al. (2007) within the alliance Bromo pannonici-Festucion pallentis. On the other hand, in older works (Klika 1931, Maglocký 1979, Mucina \& Maglocký 1985) it was considered as a part of the broadly defined alliance Seslerio-Festucion pallentis Klika 1931 corr. Zólyomi 1966. Considering the nomenclatural remark in Mucina \& Kolbek (1993: 460 ), we regard it as a nomen ambiguum. According to the presence of numerous diagnostic taxa of the alliance Bromo pannonici-Festucion pallentis in the vegetation of both associations (cf. Table 1), we agree with this newer concept.

The alliance Seslerio-Festucion pallentis has been divided into two alliances in recent literature. One of them is Bromo pannonici-Festucion pallentis. The other, Diantho lumnitzeri-Seslerion albicantis, includes the closed dealpine xerophilous vegetation on the limestone bedrock, mostly dominated by Sesleria albicans. The association Minuartio setaceae-Seslerietum caeruleae belongs to this alliance (cf. Mucina \& Kolbek 1993, Chytrý et al. 2007).

\section{DISCUSSION AND CONCLUSION}

The results of the presented numerical analyses support the traditional conceptions (Sillinger 1930, Klika 1931, Maglocký 1979), which were created through the deductive classification methods. It is very important that the clusters representing individual associations include the relevés of the original association description (cf. Fig. 2, sources of relevés). The relevés of the original description of the Festuco valesiacae-Stipetum capillatae (cluster A) are in Sillinger (1930: 36, rel. 1, 2 and 3). Cluster B (Festuco pallentis-Caricetum humilis) contains the relevés of the original description also from Sillinger (1930: 36, rel. 4, 5, 6 and 7). Cluster C (Poo badensis-Festucetum pallentis) includes a relevé from Klika (1931: 363, rel. 13). Cluster D (Minuartio setaceae-Seslerietum caeruleae) does not involve any relevés from Sillinger (1930), because there is only a synoptic table in this work. However, cluster D contains only the relevé from the Považský Inovec Mts, which occurs in Klika (1931: 370, rel. 29).

On the other hand, the cluster analyses did not support the validity of the numerous subasso- 


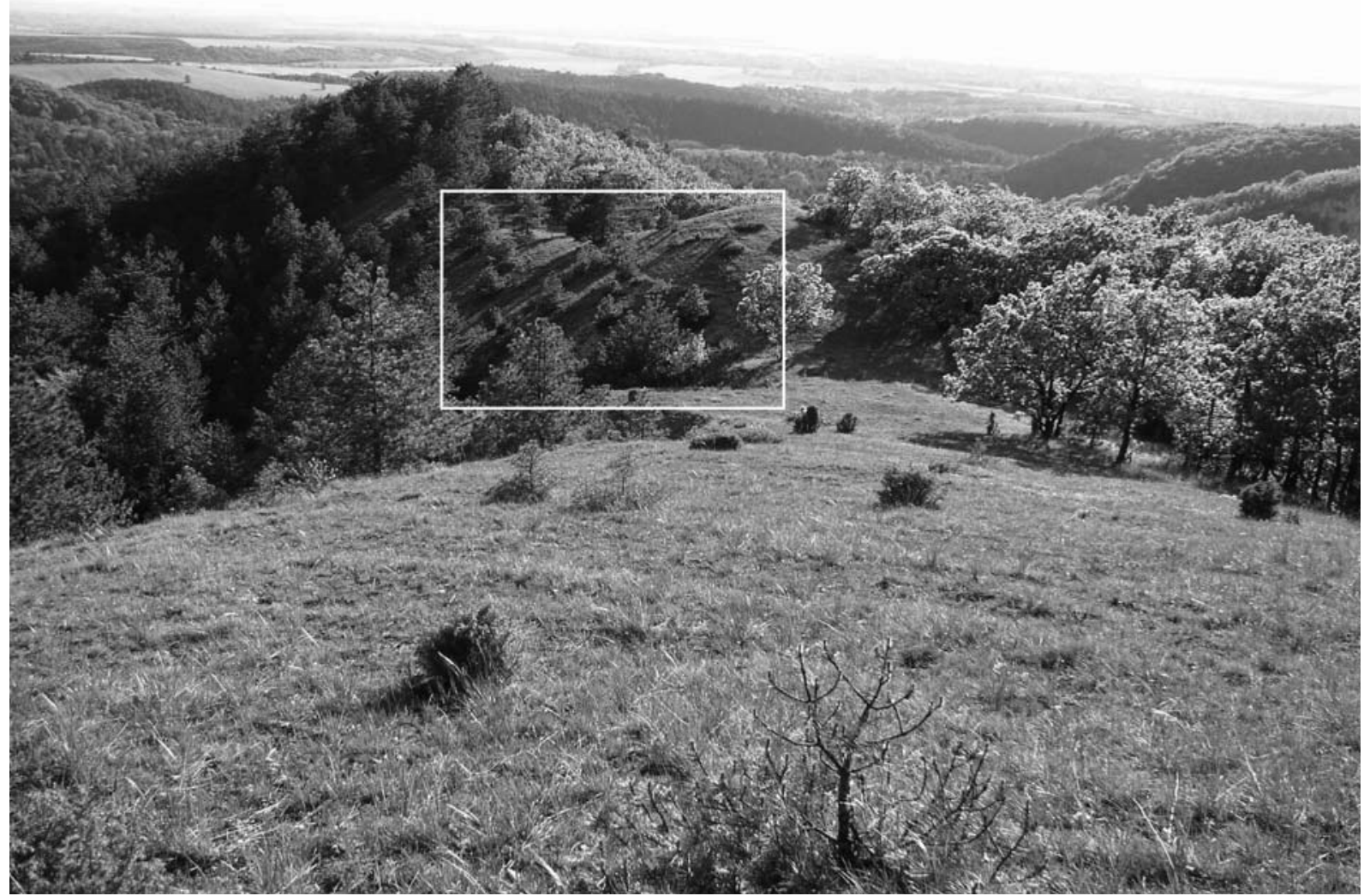

Figure 9: Influence of slope exposition on the distribution of the dry grassland associations. In front is the Festuco pallentis-Caricetum humilis. The Poo badensis-Festucetum pallentis is marked by a white rectangle in the background. Locality Hradlová nivka (township of Lúka). Photo: M. Janišová, 7. 5. 2005.

Slika 9: Vpliv naklona in nebesne lege na razširjenost asociacij suhih travnikov. V ospredju sestoji asociacije Festuco pallentisCaricetum humilis. Sestoj asociacije Poo badensis-Festucetum pallentis je označen z belim pravokotnikom v ozadju. Lokacija Hradlová nivka (občina Lúka). Foto: M. Janišová, 7. 5. 2005.

ciations and variants assigned in Maglocký (1979). According to Art. 5 of the International Code of Phytosociological Nomenclature (Weber, Moravec \& Theurillat 2000), these subassociations were invalidly described, because there was no nomenclatorical typus designated in the paper. In this study, only some relevés of Maglocký's subassociations aggregated at the lower hierarchical level of the dendrogram (Fig. 2, numbers 1-6). In the Festuco valesiacae-Stipetum capillatae festucetosum rupicoae, 8 from 9 relevés published in Maglocký (1979) grouped together. In the F. v.-S. c. botryochloetosum ischaemii it was 6 from 9 relevés and in the $F$. v.-S. c. caricetosum caryophyllae 6 from 7 relevés (Fig. 2, numbers $1-3)$. None of the subassociations described in the dry grasslands, which Maglocký named Scabioso suaveolentis-Caricetum humilis, were confirmed by the analysis. Only 5 from 8 relevés of $S$. s.-C. $h$. typicum, Koeleria macrantha-variant aggregated in the dendrogram (Fig. 2, number 4). All seven relevés of Poo badensis-Festucetum pallentis jovibarbetosum hirtae from Maglocký (1979) gathered together. Moreover two other relevés joined this group (Fig. 2, number 5). A small cluster was created by all of the three relevés of Minuartio setaceae-Seslerietum caeruleae (syn. Carici humilis-Seslerietum calcariae) festucetosum pallentis (Fig. 2, number 6). This study does not attempt to solve the problems of variability within the studied associations. For this purpose, it is necessary to analyse a representative data set consisting of the relevés from the whole area of the associations' occurrence.

Nowadays, the dry grasslands in the Považský Inovec Mts have to face many threats. First of all, the abandonment of the pastures (mostly Festuco valesiacae-Stipetum capillatae) causes successional changes in the species composition as well as shrub progression. Mostly deer and mouflons (Ovis ammon subsp. 
musimon) graze the vegetation of Festuco pallentisCaricetum humilis, which can be found at the higher altitudes, away from the settlements. However, the non-native mouflons, introduced into this area in the past, can cause the erosion (particularly in the Poo badensis-Festucetum pallentis) and increase the amount of nitrogen in the soil. In the past decades, an intensive planting of non-native Pinus nigra and Fraxinus ornus was accomplished in large areas. This destroyed or eventually reduced the size of many sites where mostly Festuco pallentis-Caricetum humilis and Minuartio setaceae-Seslerietum caeruleae had occurred. In some areas, the grasslands of Festuco valesiacae-Stipetum capillatae were completely destroyed by ploughing in order to intensify the agricultural production in the communistic times (Maglocký in verb., Deván et al. 2006).

Because of the consistent reduction of the area of the dry grasslands, it is necessary to continue with the management activities. Although this vegetation is secondary and human-influenced, it represents a refuge for many rare thermophilous species and it is a valuable contribution to the diversity of habitats in Slovakia.

\section{ACKNOWLEDGEMENTS}

The author is grateful to Milan Chytrý, Monika Janišová, Jiří Kolbek, Jozef Šibík, Milan Valachovič and Mária Zaliberová for their valuable comments on the manuscript and willingness to help with the numerical analyses. I also thank to Jana Sadloňová for helping to create the charts and to Sylvia Mertanová who made the map. Lucia Kwon performed the language correction. For intensive help in solving the nomenclatural problems, I am deeply indebted to Ján Kliment. The research study was funded by projects APVT-51-015804 and VEGA 2/5084/25.

\section{REFERENCES}

Braun-Blanquet, J. 1964: Pflanzensoziologie. Grundzüge der Vegetationskunde. Ed. 3. Springer Verlag, Wien, 865 pp.

Chytrý, M., Hoffmann, A. \& Novák, J. 2007: Suché trávníky. Třída Festuco-Brometea. In: Chytrý M. (ed.): Vegetace České republiky. 1. Travinná a keříčková vegetace. Academia, Praha. In press. http://www.sci.muni.cz/botany/vegsci/vegetace.php?lang=cz
Chytrý, M., Tichý, L., Holt, J. \& Botta-Dukát, Z. 2002: Determination of diagnostic species with statistical fidelity measures. J. Veg. Sci. 13: 79-90.

Deván, P., Devánová, K., Mered’a, P. jun., Smatanová, J. \& Rajcová, K. 2006: Charakteristika flóry záujmového územia floristického kurzu v Pruskom. Bul. Slov. Bot. Spoločn., 28, Suppl. 1: 13-21.

Ellenberg, H., Weber, H. E., Düll, R., Wirth, W. \& Werner, W. 2001: Zeigerwerte von Pflanzen in Mitteleuropa. Ed. 3. Scr. Geobot. 18: 1-262.

Holub, J., Hejný, S., Moravec, J. \& Neuhäusl, R. 1967: Übersicht der höheren Vegetationseinheiten der Tschechoslowakei. Rozpr. Českoslov. Akad. Věd, Praha 77: 3-75.

Janišová, M. 2005: Vegetation - environment relationships in dry calcareous grasslands. Ekológia, 24 (1): 25-64.

Janišová, M. 2006a: Caespitose grasses in dry grassland communities at several organization scales. In: Bültmann, H., Fartmann, T., Hasse, T. (eds): Trockenrasen auf unterschiedlichen Betrachtungsebenen. Arb. Inst. Landschaftsökol. Münster 15: 43-49.

Janišová, M. 2006b: Tiller demography of Festuca pallens Host (Graminae) in two dry grassland communities. Pol. J. Ecol. 54 (2): 201-213.

Janišová, M. 2007a: Leaf demography of Festuca pallens Host in dry grassland communities. Biologia, Bratislava (in press).

Janišová, M. 2007b: Spatial genotypical diversity of Sesleria albicans (Poaceae) in a dry grassland community. Biologia, Bratislava (submitted).

Klika, J. 1931: Studien über die xerotherme Vegetation Mitteleuropas I. Die Pollauer Berge im südlichen Mähren. Beih. Bot. Cbl. 47 B: 343398.

Maglocký, Š. 1978: Porovnanie ekoklimatických podmienok $\mathrm{v}$ rastlinných spoločenstvách na Bôrovišti (Považský Inovec). Biológia, Bratislava 33: 333 - 341.

Maglocký, Š. 1979: Xerotermná vegetácia v Považskom Inovci. Biol. Pr., Bratislava 25 (3): 1-129.

Marhold, K. \& Hindák, F. (eds) 1998: Zoznam nižších a vyšších rastlín Slovenska. Veda, Bratislava, 688 pp.

McCune, B. \& Mefford, M. J. 1999: PC-ORD. Multivariate analysis of ecological data, Version 4.0. MjM Software Design, Gleneden Beach, 237 pp.

Michalko, J., Berta, J., Magic, D., Maglocký, Š. \& Špániková, A. 1987: Geobotanical map of CSSR. Slovak socialist republic. Maps. Veda, Bratislava. 
Michálková, D. \& Šibík, J. 2006: A numerical approach to the syntaxonomy of plant communities of the class Festuco-Brometea in Slovakia. Tüxenia, Göttingen 26: 145-158.

Michálková, D., Škodová, I. \& Mertanová, S. 2006: Príspevok k fytocenológii xerotermných rastlinných spoločenstiev v Považskom Inovci. In: Rajcová, K. (ed.): Najvzácnejšie prírodné hodnoty Tematínskych vrchov. Zborník výsledkov inventarizačného výskumu územia európskeho významu Tematínske vrchy. KOZA a Pre Prírodu, Trenčín, pp. 25-44.

Moravec, J., Balátová-Tuláčková, Blažková, D., E., Hadač, E., Hejný, S., Husák, Š., Jeník, J., Kolbek, J., Krahulec, F., Kropáč, Z., Neuhäusel, R., Rybníček, B., Řehořek, V. \& Vicherek, J. 1995: Rostlinné společenstva České republiky a jejich ohrožení. Severočeskou Přír., příl. 1995, Litoměřice, Ed. 2., 206 pp.

Mucina, L. \& Kolbek, J. 1993: Festuco-Brometea. In: Mucina, L., Grabherr, G. \& Ellmauer, T. (eds): Die Pflanzengesellschaften Österreichs. Teil I. Gustav Fischer Verlag, Jena, pp. 420-492.

Mucina, L. \& Maglocký, S. (eds) 1985: A list of vegetation units of Slovakia. Docum. Phytosociol. N. S., Camerino, 9: 175-220.

Sillinger, P. 1930: Vegetace Tematínských kopců na západním Slovensku. Př́íspěvek $\mathrm{k}$ fytogeografii a fytosociologii vápencových obvodů v jihozápadních výběžcích karpatských. Rozpr. 2. Tř. České Akad. 40 (13): 1-46.
Sokal, R. R. \& Rohlf, F. J. 1995: Biometry. The principles and practice of statistics in. biological research. Ed. 3. W. H.Freeman \& Co., New York, $887 \mathrm{pp}$.

Stanová, V. \& Valachovič, M. (eds), 2002: Katalóg biotopov Slovenska. DAPHNE - Inštitút aplikovanej ekológie, Bratislava, 225 pp.

ter Braak, C. J. F. \& Šmilauer, P. 2002: CANOCO reference manual and CanoDraw for Windows user's guide. Software for canonical community ordination (version 4.5). Biometris, Wageningen \& České Budějovice, 500 pp.

Tichý, L. \& Holt, J. 2006: JUICE - program for management, analysis and classification of ecological data. First part of the program manual. http://www.sci.muni.cz/botany/juice/JC_ man1.pdf

Tichý, L. 2002: JUICE, software for vegetation classification. J. Veg. Sci., Uppsala 13: 451-453.

Toman, M. 1975: Materiál k fytocenológii společenstev třídy Festuco-Brometea na Pavlovských kopcích (Jižní Morava). Zborn. Ped. Fak. Prešov. Univ. P. J. Šafárika, Košice, 1: 127-134.

Weber, H. E., Moravec, J. \& Theurillat, J.-P. 2000: International Code of Phytosociological Nomenclature. Ed. 3. J. Veget. Sci., Uppsala 11: 739-768.

Westhoff, V., van der Maarel, E. 1973: The BraunBlanquet approach. In: Whittaker, R. H. (ed.): Ordination and Classification of Communities. Dr. W. Junk Publishers, The Hague, pp. 617727. 
Table 1: A synoptic table of four associations produced by cluster analysis. The values in first columns are percentage frequencies. The fidelities ( $\varphi$ coefficient multiplied by 100) are given in smaller characters in the second columns.

Tabela 1: Sinoptična tabela štirih asociacij narejena na osnovi rezultatov klastrske analize. Vrednosti v prvem stolpcu so frekvence $\mathrm{v}$ odstotkih. Vrednosti $\mathrm{v}$ drugi koloni (manjše številke) so navezanost ( $\varphi$ koeficient pomnožen s 100).

\begin{tabular}{lllll} 
Association (cluster) & A & B & C & D \\
\hline Number of relevés & 46 & 42 & 20 & 16 \\
Average number of species & 34 & 32 & 20 & 26 \\
Average inclination & $11^{\circ}$ & $22^{\circ}$ & $26^{\circ}$ & $28^{\circ}$ \\
\hline
\end{tabular}

\section{Festuco valesiacae-Stipetum capillatae}

Festuca valesiaca

Medicago falcata

Eryngium campestre

Securigera varia

Pimpinella nigra

Acosta rhenana agg.

Thymus pannonicus

Festuca rupicola

Carex caryophyllea

Koeleria macrantha

Astragalus onobrychis

Medicago lupulina

Plantago lanceolata

Poa angustifolia

Salvia pratensis

Fragaria viridis

Teucrium chamaedrys

Galium verum

Adonis vernalis

Agrimonia eupatoria

Achillea collina

Ranunculus bulbosus

Festuco pallentis-Caricetum humilis

Alyssum montanum B-F

Stipa joannis

Poa badensis B-F

Colymbada scabiosa agg.

Poo badensis-Festucetum pallentis

Festuca pallens B-F

Fumana procumbens B-F

Draba lasiocarpa

Minuartio setaceae-Seslerietum caeruleae

Sesleria albicans D-S

Genista pilosa

87

76

63

48

63

50

39

50

39

72

28

28

35

37

26

33

80

22

22

22

35

24

37

37
4

4
7

11

7

Thalictrum minus

Thesium linophyllon

Phyteuma orbiculare D-S

Allium *montanum D-S

Thlaspi montanum D-S

Bupleurum falcatum

.

2

4

7
13

$$
\begin{aligned}
& 77,8 \\
& 74,4 \\
& 69,1 \\
& 61,5 \\
& 60,8 \\
& 57,7 \\
& 54,4 \\
& 52,9 \\
& 49,8 \\
& 48,5 \\
& 47,8 \\
& 47,8 \\
& 46,7 \\
& 46,4 \\
& 45,7 \\
& 44,6 \\
& 44,2 \\
& 41,5 \\
& 41,5 \\
& 41,5 \\
& 41,4 \\
& 40,4
\end{aligned}
$$

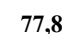

\section{.--
-}

--
$--\quad 38$

40

$-33$

.$--\quad 76$
--2

---57
$-\quad 5$

$--\quad 21$

76
21

22,7
21,8
---

100

85

50

50,5

$\mathbf{5 4 , 8}$

44,6

17

$---5$

---

29

$--$

$$
\text { . }
$$

$-100$

100

96,9

4 


\begin{tabular}{|c|c|c|c|c|c|c|c|c|}
\hline \multirow{2}{*}{$\begin{array}{l}\text { Association (cluster) } \\
\text { Polygala *brachyptera D-S }\end{array}$} & \multicolumn{2}{|c|}{ A } & \multicolumn{2}{|c|}{ B } & \multicolumn{2}{|c|}{$\mathbf{C}$} & \multicolumn{2}{|c|}{ D } \\
\hline & 4 & -- & ? & --- & . & --- & 38 & 51 \\
\hline Campanula moravica & 7 & ..- & 24 & -.- & 60 & -.- & 88 & 50 \\
\hline Bromus monocladus & . & --- & . & --- & . & --- & 25 & 44,7 \\
\hline \multicolumn{9}{|l|}{ Festucion valesiacae } \\
\hline Carex humilis & 28 & --- & 100 & 40,5 & 40 & --- & 100 & 40,5 \\
\hline Silene otites & 15 & --- & 55 & 34,2 & 30 & --- & 12 & -- \\
\hline Asperula cynanchica & 61 & --- & 62 & --- & 55 & --- & 38 & --- \\
\hline Erysimum odoratum & 11 & --- & 17 & --- & 5 & --- & 19 & --- \\
\hline Pilosella bauhinii & 33 & --- & 38 & --- & 60 & --- & 44 & --- \\
\hline Allium flavum & 24 & --- & 40 & --- & 45 & --- & 19 & -- \\
\hline Scabiosa ochroleuca & 52 & --- & 40 & --- & 20 & --- & 44 & -- \\
\hline Jurinea mollis & 4 & --- & 26 & --- & 25 & --- & 12 & --- \\
\hline Onosma visianii & 2 & --- & 36 & 34,9 & 20 & --- & . & -- \\
\hline Stachys recta & 15 & --- & 26 & --- & 10 & --- & . & -- \\
\hline Veronica prostrata & 22 & --- & 7 & --- & 5 & --- & . & -- \\
\hline Pseudolysimachion spicatum & 4 & --- & 21 & --- & . & --- & 25 & --- \\
\hline Artemisia campestris & 17 & --- & 10 & --- & . & --- & 6 & --- \\
\hline Seseli hippomarathrum & 15 & --- & 12 & --- & . & --- & 6 & --- \\
\hline Vincetoxicum hirundinaria & . & --- & 31 & 33,3 & 5 & --- & 12 & -- \\
\hline Bothriochloa ischaemum & 39 & 37,1 & 24 & --- & . & --- & . & --- \\
\hline Dianthus carthusianorum & 28 & 39,5 & 7 & --- & . & --- & . & --- \\
\hline Stipa capillata & 33 & --- & 36 & --- & . & --- & . & -- \\
\hline Arenaria leptoclados & 7 & --- & 10 & --- & . & --- & . & --- \\
\hline Elytrigia intermedia & 17 & 36,9 & . & --- & . & --- & . & -- \\
\hline Medicago minima & 17 & 36,9 & . & --- & . & --- & . & -- \\
\hline \multicolumn{9}{|c|}{ Bromo pannonici-Festucion pallentis } \\
\hline Thymus praecox & 37 & --- & 93 & 30,4 & 100 & 39,3 & 44 & --- \\
\hline Teucrium montanum & 28 & --- & 83 & --- & 100 & 30,8 & 100 & --- \\
\hline Melica ciliata & 20 & --- & 57 & 33,5 & 45 & --- & . & -- \\
\hline Potentilla arenaria & 74 & --- & 83 & --- & 65 & --- & 38 & -- \\
\hline Campanula sibirica & 11 & --- & 52 & 23,8 & 50 & --- & 19 & --- \\
\hline Scorzonera austriaca & 4 & --- & 48 & 38,8 & 5 & --- & 25 & --- \\
\hline Sedum album & 2 & --- & 24 & --- & 45 & --- & 25 & --- \\
\hline Jovibarba *glabrescens & 7 & --- & 38 & --- & 45 & --- & 19 & -- \\
\hline Scabiosa canescens & 2 & --- & 24 & --- & 5 & --- & 19 & --- \\
\hline \multicolumn{9}{|c|}{ Diantho lumnitzeri-Seslerion albicantis } \\
\hline Leontodon incanus & 17 & --- & 69 & --- & 85 & --- & 75 & --- \\
\hline Biscutella laevigata & 4 & --- & 19 & --- & 40 & --- & 50 & --- \\
\hline \multicolumn{9}{|l|}{ Seslerio-Festucion pallenis } \\
\hline Anthericum ramosum & 7 & --- & 60 & --- & 45 & --- & 81 & 38,3 \\
\hline Linum tenuifolium & 33 & --- & 64 & 31,3 & 30 & --- & 25 & --- \\
\hline Seseli osseum & 22 & --- & 48 & --- & 30 & --- & 31 & --- \\
\hline Dianthus *lumnitzerii & 7 & --- & 38 & --- & 45 & --- & 38 & --- \\
\hline Minuartia rubra & 13 & --- & 17 & --- & 20 & --- & . & --- \\
\hline Dorycnium herbaceum agg. & 17 & --- & 12 & --- & . & --- & 6 & --- \\
\hline Cyanus triumfetti & 2 & --- & 5 & --- & . & --- & 6 & --- \\
\hline Galium glaucum & 9 & --- & 7 & --- & . & --- & 19 & -- \\
\hline Saxifraga tridactylites & 2 & --- & 2 & --- & 15 & --- & . & --- \\
\hline Hornungia petraea & . & --- & 19 & --- & 10 & --- & . & --- \\
\hline \multicolumn{9}{|l|}{ Festucetalia valesiacae } \\
\hline Inula ensifolia & 9 & --- & 33 & --- & 10 & --- & 25 & --- \\
\hline
\end{tabular}




\begin{tabular}{|c|c|c|c|c|c|c|c|c|}
\hline \multirow{2}{*}{$\begin{array}{l}\text { Association (cluster) } \\
\text { Linaria genistifolia }\end{array}$} & \multicolumn{2}{|c|}{ A } & \multicolumn{2}{|c|}{ B } & \multicolumn{2}{|c|}{ C } & \multicolumn{2}{|c|}{ D } \\
\hline & 15 & -- & 24 & --- & . & --- & 6 & --- \\
\hline Viola collina & . & --- & 5 & --- & 10 & --- & 31 & --- \\
\hline Veronica austriaca & . & --- & 7 & --- & . & --- & 19 & -- \\
\hline Lactuca viminea & 17 & 36,9 & . & --- & . & --- & . & -- \\
\hline \multicolumn{9}{|l|}{ Festuco-Brometea } \\
\hline Helianthemum grandiflorum & 48 & --- & 93 & 20,4 & 85 & --- & 88 & -- \\
\hline Sanguisorba minor & 83 & --- & 93 & --- & 50 & --- & 69 & -- \\
\hline Tithymalus cyparissias & 72 & --- & 86 & --- & 60 & --- & 50 & --- \\
\hline Carlina vulgaris & 17 & --- & 10 & --- & 5 & --- & 6 & -- \\
\hline Acinos arvensis & 30 & 35,1 & 10 & --- & 5 & --- & . & -- \\
\hline Arenaria serpyllifololia & 13 & --- & 26 & --- & 25 & --- & . & -- \\
\hline Allium sphaerocephalon & 2 & --- & 7 & --- & 5 & --- & . & --- \\
\hline Arabis hirsuta & 20 & --- & 31 & --- & . & --- & 12 & -- \\
\hline Pimpinella saxifraga & 11 & --- & 10 & --- & . & --- & 19 & -- \\
\hline Plantago media & 28 & --- & 10 & --- & . & --- & 44 & -- \\
\hline Potentilla heptaphylla & 17 & --- & 12 & --- & . & --- & 44 & --- \\
\hline Trinia glauca & 17 & --- & 7 & --- & 5 & --- & . & -- \\
\hline Seseli annuиm & 20 & 35,7 & 2 & --- & . & --- & . & -- \\
\hline Leontodon hispidus & 20 & 30,8 & . & --- & . & --- & 6 & --- \\
\hline Trifolium campestre & 17 & --- & . & --- & . & --- & 6 & -- \\
\hline Crinitina linosyri & 11 & --- & 10 & --- & . & --- & . & -- \\
\hline Avenula pubescens & 9 & --- & 10 & --- & . & --- & . & -- \\
\hline Phleum phleoides & 20 & 39,3 & $\cdot$ & --- & . & --- & . & -- \\
\hline \multicolumn{9}{|l|}{ Other taxa } \\
\hline Pilosella officinarum & 61 & 34,9 & 38 & --- & 25 & --- & 6 & -- \\
\hline Globularia punctata & 15 & -- & 86 & 33,4 & 65 & --- & 62 & -- \\
\hline Anthyllis vulneraria & 37 & --- & 64 & 29 & 20 & --- & 38 & -- \\
\hline Sedum acre & 11 & --- & 12 & --- & 20 & --- & 6 & -- \\
\hline Asperula tinctoria & 2 & --- & 10 & --- & 5 & --- & 25 & -- \\
\hline Sedum sexangulare & 46 & --- & 33 & --- & 25 & --- & . & -- \\
\hline Thlaspi perfoliatum & 37 & --- & 29 & --- & 20 & --- & . & -- \\
\hline Arabis auriculata & 24 & --- & 5 & --- & 15 & --- & . & -- \\
\hline Cerastium brachypetalum & 7 & --- & 7 & --- & 25 & --- & . & -- \\
\hline Cerastium pumilum & 7 & --- & 7 & --- & 5 & --- & . & -- \\
\hline Pulsatilla grandis & . & --- & 7 & --- & 10 & --- & 12 & --- \\
\hline Acinos alpinus & . & --- & 2 & --- & 15 & --- & 19 & -- \\
\hline Galium austriacum & & -- & 5 & --- & 20 & --- & 19 & -- \\
\hline Hypericum perforatum & 37 & --- & 24 & --- & . & -- & 6 & -- \\
\hline Euphrasia stricta agg. & 13 & --- & 5 & --- & . & --- & 19 & -- \\
\hline Hippocrepis comosa & 9 & --- & 5 & --- & . & --- & 12 & -- \\
\hline Pulsatilla slavica & 2 & --- & 7 & --- & . & --- & 6 & -- \\
\hline Inula hirta & 2 & --- & 5 & --- & . & --- & 6 & --- \\
\hline Silene vulgaris & 2 & -- & 2 & -- & . & --- & 6 & --- \\
\hline Linum catharticum & 30 & 31,9 & . & --- & . & --- & 19 & -- \\
\hline Sideritis montana & 17 & 36,9 & . & --- & . & --- & . & -- \\
\hline Chondrilla juncea & 15 & 34,4 & . & --- & . & --- & . & -- \\
\hline
\end{tabular}

\section{Abreviations:}

A - Festuco valesiacae-Stipetum capillatae Sillinger 1930, B - Festuco pallentis-Caricetum humilis Sillinger 1930 corr. Gutermann et Mucina 1993, C - Poo badensis-Festucetum pallentis Klika 1931 corr. Zólyomi 1966 nom. invers. propos., D - Minuartio setaceae-Seslerietum caeruleae Klika, B-F - Bromo pannonici-Festucion pallentis Zólyomi 1936 corr. 1966, D-S - Diantho lumnitzeri-Seslerion albicantis (Soó 1971) Chytrý et Mucina in Mucina et Kolbek 1993. 